УДК $339.14+664.76$

DOI: $10.15673 /$ fie.v13i2.2035

\author{
Нікішина О.В. \\ доктор економічних наук, старший науковий співробітник \\ завідувач відділу ринкових механізмів та структур \\ Інститут проблем ринку та економіко-екологічних досліджень НАН України \\ Французький бульвар, 29, м. Одеса, Україна, 65044 \\ E-mail: ksenkych@gmail.com \\ ORCID ID: 0000-0002-7172-3551
}

\title{
ДІАГНОСТИКА ПОКАЗНИКІВ ДОДАНОЇ ВАРТОСТІ ТА ЛОГІСТИЧНИХ ВИТРАТ У ЛАНЦЮГУ РИНКУ ЗЕРНОВИХ І ХЛІБНИХ ПРОДУКТІВ УКРАїНИ *
}

\begin{abstract}
Стаття присвячена емпіричному дослідженню ланкових показників доданої вартості й логістичних витрат у ланцюгу ринку зернових і хлібних продуктів України. Визначено міжланкові співвідношення головних показників ефективності та відтворювальні диспропорції у розвитку ринкового ланцюга. Встановлено, що у міру зростання ступеню переробки продукції в ланцюгу «пшениця - борошно - хліб», рівень її рентабельності зменшується за одночасного зростання податкового навантаження та зміни структури доданої вартості в напрямі збільшення частки заробітної плати та скорочення питомої ваги прибутку. Доведено, що ланка виробництва хлібобулочних виробів, виконуючи вагому соціальну й податкову роль в ринковій системі, недоотримує додану вартість, що гальмує її відтворювальний розвиток на інноваційній основі. Наголошено, що невирішеність проблеми структурних диспропорцій у ланцюгу ринку зернових і хлібних продуктів поступово трансформує цей ланцюг в напрямі скорочення завершеного циклу переробки та міграції доданої вартості у «тіньові» сфери переробних ланок. Проведено діагностику логістичних витрат у ланковому вимірі, вперше розраховано логістичну компоненту доданої вартості. Визначено напрями і заходи продовження ринкового ланцюга вартості у контексті досягнення цілей Національної економічної стратегії до 2030 p.
\end{abstract}

Ключові слова: ринковий ланцюг, діагностика, додана вартість, логістичні витрати, зернові та хлібні продукти, відтворювальний розвиток.

This work is licensed under a Creative Commons Attribution 4.0 International License http://creativecommons.org/licenses/by/4.0/

Постановка проблеми та їі зв'язок 3 важливими науковими та практичними завданнями. В сучасних умовах економічної невизначеності та необхідності адаптації управлінських рішень до змін параметрів зовнішнього і внутрішнього середовища вагомого значення набувають дослідження відтворювальних процесів у ланцюгах стратегічних товарних ринків зокрема, агропродовольчих. Діагностика тенденцій і закономірностей розвитку ринкових ланцюгів, показників ефективності їх ланок, причиннонаслідкових зв'язків між ними, логістичних «розривів» потокових процесів дає можливість сформувати потужний аналітичний фундамент для обгрунтування стратегічних напрямів і адаптивних механізмів відтворювально-логістичного розвитку товарних ринків. Сучасні трансформації ринкових процесів відтворення у ланковому та ланцюговому вимірі обумовлюють необхідність вдосконалення існуючих методичних підходів та розробки нових показників, здатних глибше оцінити динамічні відтворювальні трансформаціï.
Ключовим індикатором для оцінки ефективності економічних систем мікро-, мезо та макрорівнів $\epsilon$ додана вартість (далі - ДВ), ресурсна структура якої відображає економічні інтереси усіх учасників логістичних процесів (працівників, суб'єктів господарювання, держави та споживачів). Діагностика формування та перерозподілу ДВ між ланками ринкових ланцюгів $\epsilon$ важливою складовою системної діагностики ефективності функціонування товарних ринків, оскільки дозволяє встановити латентні структурні диспропорції відтворювальних процесів, що не помітні в ході аналізу ринкової кон'юнктури.

Проблематика дослідження тісно пов'язана зі стратегічними цілями і напрямами розвитку агропромислового сектору, визначеними Національною економічною стратегією на період до 2030 р. [1], що акцентують увагу на продовженні агропродовольчих ланцюгів доданої вартості, переорієнтації сировинного експорту на продукцію з високою ДВ, логістичному розвитку ринкових ланцюгів, оптимізації збутової системи на внутрішньому та зовнішньому ринках.

*Публікацію підготовлено в межах виконання НДР «Формування ефективної логістики товарних ринків» (№ державної реєстрації 0119U000227). 
Аналіз останніх публікацій по проблемі. Теоретико-методичні засади оцінки доданої вартості та логістичних витрат на мікрорівні висвітлено в дослідженнях О.Б. Гірної, Н.Ю. Глинського, О.Я. Кобилюх [2], Р.Р. Ларіної, Д. Кочубея, С.М. Осипенко, Посилкіної О.В. [3], О.М. Сумця [4], Н.В. Чорнописької та інших учених. Науковоприкладні дослідження формування доданої вартості на макрорівні (у секторальному вимірі) проводили В.Ф. Горячук, Ю.А. Назаренко [5], О.В. Коваленко [6], А.Л. Педорченко, О.О. Шпичак [7] та інші економісти. Питання розробки методології відтворювальної логістики товарних ринків знаходиться в центрі уваги науковців Інституту проблем ринку та економіко-екологічних досліджень НАН України, зокрема, Б.В. Буркинського [8], В.М. Лисюка, М.Л. Тараканова [9], Т.П. Лозової [10]. Водночас недостатньо дослідженим залишається питання відтворювальних пропорцій і диспропорцій у ринкових ланцюгах, закономірностей формування й розподілу доданої вартості у ланцюгах певних товарних ринків, що актуалізує розробки у даному напрямі.

Формулювання цілей дослідження. Мета cmammi - емпіричне дослідження ланкових показни- ків доданої вартості й логістичних витрат у ланцюгу вітчизняного ринку зернових і хлібних продуктів (далi - ЗХП), визначення міжланкових співвідношень головних показників ефективності та відтворювальних диспропорцій у розвитку ринкового ланцюга, як аналітичного підгрунтя для розробки адаптивних механізмів і заходів їх подолання.

Виклад основних результатів та їх обгрунтування. Методичним базисом емпіричного дослідження ланкових показників ефективності $є$ методичні положення діагностики ефективності функціонування логістичних ланцюгів товарних ринків [11]. Першим етапом діагностики є побудова міжланкового товарного балансу (таблиця 1), який за допомогою технологічних норм виходу продукції дозволяє визначити обсяги товаропотоків у логістичному ланцюгу «пшениця - борошно - хліб та хлібобулочні вироби нетривалого зберігання». За даними логістичного балансу, в 2019 р. для виробництва 893 тис. т хліба та хлібобулочних виробів було використано 43 \% випуску пшеничного борошна і всього 3,4 \% валового збору пшениці в країні; у середньому за 2015-2019 рр. ці показники склали 46,8 \% і 4,4% відповідно.

Таблиця 1

Міжланковий товарний баланс у логістичному ланцюгу ринку 3ХП"

\begin{tabular}{|c|c|c|c|c|c|c|c|}
\hline \multirow{2}{*}{ Роки } & \multicolumn{2}{|c|}{ Ланка 1: Пшениця } & \multicolumn{2}{|c|}{ Ланка 2: Борошно } & \multirow{2}{*}{$\begin{array}{c}\text { Ланка 3: ХХБВ } \\
\text { нетривалого } \\
\text { зберігання } \\
\text { тис. т } \\
\text { (вихід } 119,62 \% \text { ) }\end{array}$} & \multicolumn{2}{|c|}{$\begin{array}{c}\text { Довідково: обсяги } \\
\text { загальнодержавно- } \\
\text { го виробниитва: }\end{array}$} \\
\hline & тис. т & $\begin{array}{c}y \% \text { до зага- } \\
\text { льного виро- } \\
\text { бництва }\end{array}$ & $\begin{array}{c}\text { тис. т (ви- } \\
\text { хід 77\%) }\end{array}$ & $\begin{array}{c}\text { у\% до зага- } \\
\text { льного ви- } \\
\text { робництва }\end{array}$ & & $\begin{array}{c}\text { пшениці, } \\
\text { тис. } m\end{array}$ & $\begin{array}{c}\text { борошна, } \\
\text { тис. } m\end{array}$ \\
\hline 2015 & 1337,6 & 5,0 & 1029,9 & 50,1 & 1232 & 26532 & 2056 \\
\hline 2016 & 1259,4 & 4,8 & 969,7 & 49,1 & 1160 & 26093 & 1974 \\
\hline 2017 & 1164,9 & 4,5 & 897,0 & 45,1 & 1073 & 26159 & 1991 \\
\hline 2018 & 1058,5 & 4,3 & 815,1 & 46,7 & 975 & 24606 & 1746 \\
\hline 2019 & 969,5 & 3,4 & 746,5 & 43,0 & 893 & 28328 & 1738 \\
\hline $\begin{array}{l}\text { Середній } \\
\text { показник }\end{array}$ & 1158,0 & 4,4 & 891,7 & 46,8 & 1066,6 & 26343,6 & 1901,0 \\
\hline
\end{tabular}

*Розраховано автором за даними Державної служби статистики України $[12,13]$

Міжланковий товарний баланс є своєрідним натуральним фундаментом вартісної оцінки показників ефективності ринкового ланцюга у ланковому вимірі. Міжланкове порівняння базових показників розвитку дозволяє визначити головні тенденції, структурні диспропорції та системні логістичні «розриви» в матеріалопровідному ланцюгу ринку. Слід зазначити, що в табл. 1 наведено логістичний баланс ринку ЗХП для сфери регламентованого товароруху, обсяг якої визначено на основі офіційних даних Державної служби статистики України щодо випуску хліба та хлібобулочних виробів (далі - ХББВ) нетривалого зберігання (ланка 3).

Другим етапом діагностики є розрахунок системи показників доданої вартості у ланковому й ланцюговому вимірі, а також ланкової й ресурсної структури ДВ. Використовуючи дані аналітичних видань стосовно витрат на виробництво продукції у логістичному ланцюгу «пшениця — борошно - хліб та хлібобулочні вироби» й офіційні дані Державної служби статистики України $[12,13,14,15,16]$, розраховано головні показники формування й розподілу доданої вартості у ланках ланцюга вітчизняного ринку ЗХП за 2015-2019 рр. Результати проведених розрахунків узагальнено в таблиці 2.

У 2019 р. порівняно з 2015 р. характерною є тенденція зростання обсягів ДВ у переробних ланках ринкового ланцюга (ланки 2 і 3), при цьому темпи іiі приросту (8 \% і 35,8 \%) є нижчими порівняно з темпами приросту собівартості борошна та ХХБВ (19,8 \% і 46,7 \% відповідно), що негативно вплинуло на рівень відтворювальної рентабельності даних ланок (скорочення склало 1,3 i 1,4 \%). Для торговельної ланки справедливим є зворотне співвідношення темпів приросту доданої вартості і собівартості, що забезпечило приріст відтворювальної рентабельності на $2,4 \%$. 
Динаміка показників формування й розподілу ланкової доданої вартості у ланцюгу українського ринку ЗХП, \%*

\begin{tabular}{|c|c|c|c|c|c|c|}
\hline \multirow{2}{*}{ Показники } & \multicolumn{5}{|c|}{ Роки } & \multirow{2}{*}{$\begin{array}{l}\text { Динаміка } \\
\text { змін }(+,-)\end{array}$} \\
\hline & 2015 & 2016 & 2017 & 2018 & 2019 & \\
\hline \multicolumn{7}{|c|}{ Ланка 1: Виробництво пшениці } \\
\hline 1. Ланкова ДВ, млн. грн. & 1419,8 & 1533,9 & 1699,3 & 1846,7 & 1129,4 & $-290,4$ \\
\hline 2. Випуск продукції, млн. грн. & 3231,2 & 3672,2 & 4443,7 & 4854,4 & 3952,7 & $+721,5$ \\
\hline 3. Частка ДВ у випуску продукції & 43,94 & 41,77 & 38,24 & 38,04 & 28,57 & $-15,37$ \\
\hline $\begin{array}{l}\text { 4. Відтворювальна рентабельність } \\
\text { продукції }\end{array}$ & 59,94 & 55,01 & 48,49 & 47,40 & 34,60 & $-25,34$ \\
\hline 5. Рентабельність продукції & 36,40 & 31,70 & 26,80 & 24,60 & 11,80 & $-24,60$ \\
\hline 6. Податкомісткість ДВ, грн./грн. & 0,063 & 0,092 & 0,102 & 0,101 & 0,101 & $+0,038$ \\
\hline 7. Частка ланки у ланцюговій ДВ & 35,75 & 33,94 & 34,41 & 34,99 & 23,53 & $-12,22$ \\
\hline \multicolumn{7}{|c|}{ Ланка 2: Виробництво борошна } \\
\hline 1. Ланкова ДВ, млн. грн. & 533,4 & 581,3 & 559,9 & 570,6 & 576,3 & $+42,9$ \\
\hline 2. Випуск продукції, млн. грн. & 4191,5 & 4450,9 & 4746,7 & 4872,3 & 4957,1 & $+765,6$ \\
\hline 3. Частка ДВ у випуску продукції & 12,73 & 13,06 & 11,80 & 11,71 & 11,62 & $-1,10$ \\
\hline $\begin{array}{l}\text { 4. Відтворювальна рентабельність } \\
\text { продукції }\end{array}$ & 13,27 & 13,67 & 12,17 & 12,07 & 11,97 & $-1,30$ \\
\hline 5. Рентабельність продукції & 4,30 & 4,70 & 3,20 & 3,10 & 3,00 & $-1,30$ \\
\hline 6. Податкомісткість ДВ, грн./грн. & 0,336 & 0,337 & 0,332 & 0,331 & 0,331 & $-0,005$ \\
\hline 7. Частка ланки у ланцюговій ДВ & 13,43 & 12,86 & 11,34 & 10,81 & 12,01 & $-1,42$ \\
\hline \multicolumn{7}{|c|}{ Ланка 3: Виробництво ХББВ нетривалого зберігання } \\
\hline 1. Ланкова ДВ, млн. грн. & 1545,9 & 1809,1 & 1885,8 & 1983,3 & 2099,1 & $+553,2$ \\
\hline 2. Випуск продукції, млн. грн. & 8588,6 & 9921,1 & 11012,4 & 11692,1 & 12434,0 & $+3875,4$ \\
\hline 3. Частка ДВ у випуску продукції & 18,00 & 18,24 & 17,12 & 16,96 & 16,88 & $-1,12$ \\
\hline $\begin{array}{l}\text { 4. Відтворювальна рентабельність } \\
\text { продукції }\end{array}$ & 18,74 & 19,04 & 17,64 & 17,44 & 17,34 & $-1,40$ \\
\hline 5. Рентабельність продукції & 4,10 & 4,40 & 3,00 & 2,80 & 2,70 & $-1,40$ \\
\hline 6. Податкомісткість ДВ, грн. / грн. & 0,339 & 0,339 & 0,336 & 0,336 & 0,335 & $-0,004$ \\
\hline 7. Частка ланки у ланцюговій ДВ & 38,92 & 40,03 & 38,19 & 37,58 & 43,74 & 4,81 \\
\hline \multicolumn{7}{|c|}{ Ланка 4: Торгівля ХББВ нетривалого зберігання } \\
\hline 1. Ланкова ДВ, млн. грн. & 472,4 & 595,3 & 792,9 & 876,9 & 994,7 & $+522,3$ \\
\hline 2. Випуск продукції, млн. грн. & 9061,1 & 10516,4 & 11805,3 & 12569,1 & 13428,7 & $+4367,6$ \\
\hline 3. Частка ДВ у випуску продукції & 5,21 & 5,66 & 6,72 & 6,98 & 7,41 & 2,19 \\
\hline $\begin{array}{l}\text { 4. Відтворювальна рентабельність } \\
\text { продукції }\end{array}$ & 5,39 & 5,86 & 7,00 & 7,29 & 7,76 & $+2,38$ \\
\hline 5. Рентабельність продукції, \% & 5,30 & 3,46 & 4,22 & 4,45 & 4,80 & $-0,50$ \\
\hline 6. Податкомісткість ДВ, грн. / грн. & 0,287 & 0,292 & 0,289 & 0,288 & 0,286 & $-0,001$ \\
\hline 7. Частка ланки у ланцюговій ДВ & 11,89 & 13,17 & 16,06 & 16,62 & 20,73 & 8,83 \\
\hline Загальна ланцюгова ДВ & 3971,57 & 4519,58 & 4937,93 & 5277,49 & 4799,48 & $+827,91$ \\
\hline
\end{tabular}

Розраховано автором за даними Державної служби статистики України, офіційних аналітичних видань [12-16], власного моніторингу 
У сировинній ланці зростаючий тренд доданої вартості, що мав місце в 2016-2018 pp., у 2019 р. змінився на протилежний внаслідок подвійного скорочення рентабельності пшениці (з 24,6 до 11,8 \%), відтак, ланкова додана вартість зменшилася на 20,5 \% за одночасного зростання собівартості зерна (див. табл. 2).

У звітному році порівняно з 2015 р. загальна ланцюгова додана вартість зросла на 20,9 \% і склала 4,8 млрд. грн. У ланковій структурі ланцюгової доданої вартості найбільша частка припадає на виробниц- тво хліба та хлібобулочних виробів (43,7 \% в 2019 р.) та вирощування пшениці (23,5%). При цьому за досліджуваний період частка переробної ланки збільшилася на 4,8 \%, частка сировинної - скоротилася на 12,2\% (рис. 1). Слід відзначити, що в 2015 р. частка торговельної ланки в ланцюговій доданій вартості була найменшою серед ланок (11,9\%); іiї зростання в наступні періоди обумовлено скороченням обсягів виробництва борошна та рівня рентабельності пшениці, що, безумовно, вплинуло на зміну ланкової структури ланцюгової ДВ.

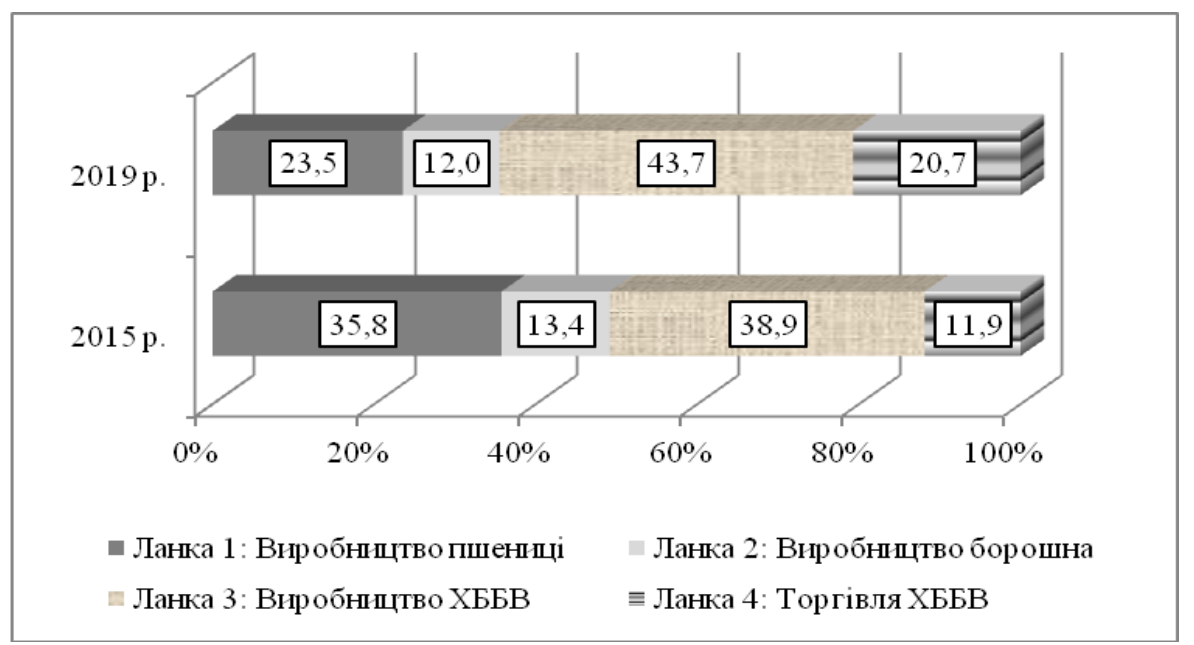

Рис.1. Ланкова структура доданої вартості у ланцюгу ринку зернових і хлібних продуктів України, \%* "Побудовано автором за даними табл. 2.

Показник частки доданої вартості у випуску продукції найвищим $є$ у сировинній ланці ринкового ланцюга $(28,6 \%)$, водночас його рівень істотно скоротився з 43,9\% в 2015 р. до $28,6 \%$ в 2019 р. внаслідок потрійного падіння рентабельності зерна (див. табл. 2). У переробних ланках частка доданої вартості у випуску борошна та ХББВ склала 16,9\% і 11,6\% відповідно та повільно зменшується. Найнижчий рівень показника притаманний торговельній ланці. Динаміка змін відтворювальної рентабельності у сировинній і переробних ланках ринкового ланцюга має перманентно знижувальний тренд, у торговельній ланці ї величина зростає. Найвищий рівень відтворювальної рентабельності характерний для зернової ланки $(34,6 \%)$.

Для оцінки розподілу ланкової ДВ за напрямом іiі фіскального використання передбачено розрахунок показника податкомісткості доданої вартості. Він визначає величину податкових надходжень у розрахунку на 1 грн. новоствореної вартості у ланковому або ланцюговому вимірі. У 2019 р. в ланцюгу вітчизняного ринку ЗХП на 1 грн. доданої вартості припадало 26,9 коп. податкових платежів, що на $15,5 \%$ вище величини 2015 р. При цьому найвищий рівень податкомісткості ДВ характерний для переробних ланок ринкового ланцюга (понад 0,33 грн./грн.), найнижчий - для сировинної ланки (0,10 грн. / грн.). Динаміка змін даного індикатора $є$ зростаючою для зер- нової ланки та знижувальною для інших ланок логістичного ланцюга ринку ЗХП (див. табл. 2).

За 2015-2019 рр. величина ланцюгових податкових надходжень зросла на $40 \%$ і склала близько 1,3 млрд. грн. У ланковій структурі податків найвищою є частка ланки виробництва ХХБВ нетривалого зберігання (54,4 \% у 2019 р.), найнижчою - сировинної ланки (рис. 2).

Динаміка змін ресурсної структури ланкової доданої вартості у ланцюгу ринку зернових і хлібних продуктів за 2015-2019 рр. наведена в таблиці 3. Особливістю структури доданої вартості сировинної ланки є їі нестабільність і значні динамічні зміни, обумовлені, передусім, варіативністю рентабельності виробництва пшениці, його залежністю від погодних умов. За досліджуваний період трьохразове скорочення рентабельності пшениці докорінно змінило ऑiі структуру доданої вартості в напрямі зменшення частки прибутку (з 60,7 \% до 34,1 \%) та зростання інший складових, зокрема амортизації необоротних активів на 11,8 \% та заробітної плати на 8,3\%.

У ресурсній структурі новоствореної вартості в ланках виробництва ХББВ та борошна найвагомішою компонентою $\epsilon$ заробітна плата $(59,5 \%$ i $47,5 \%$ ), що має незначний зростаючий тренд (понад 4,5 \%) та є свідченням провідної ролі даних ланок у реалізації економічних інтересів зайнятих у цих ланках працівників. 


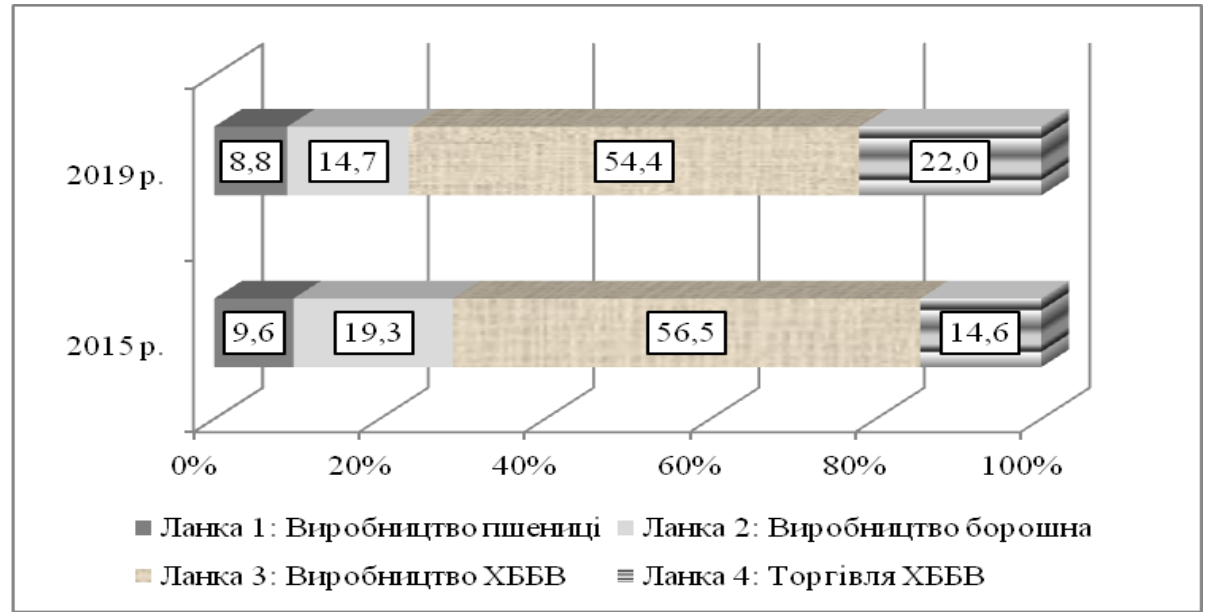

Рис. 2. Ланкова структура податкових надходжень у ланцюгу ринку зернових і хлібних продуктів України, \%*

*Побудовано автором за даними табл. 2.

Ресурсна структура ланкової доданої вартості у ланцюгу українського ринку зернових і хлібних продуктів, \%*

\begin{tabular}{|c|c|c|c|c|c|c|}
\hline \multirow[b]{2}{*}{ Складові } & \multicolumn{5}{|c|}{ Роки } & \multirow{2}{*}{$\begin{array}{l}\text { Динаміка } \\
\text { змін }(+,-)\end{array}$} \\
\hline & 2015 & 2016 & 2017 & 2018 & 2019 & \\
\hline \multicolumn{7}{|c|}{ Ланка 1: Виробництво пшениці } \\
\hline 1. Заробітна плата & 11,31 & 10,54 & 13,47 & 14,35 & 19,65 & $+8,34$ \\
\hline 2. Амортизація необоротних активів & 8,44 & 9,66 & 12,70 & 14,77 & 20,23 & $+11,79$ \\
\hline 3. Оренда земельних паїв & 19,52 & 22,18 & 18,56 & 18,99 & 26,01 & $+6,49$ \\
\hline 4. Прибуток & 60,73 & 57,62 & 55,27 & 51,90 & 34,10 & $-26,63$ \\
\hline \multicolumn{7}{|c|}{ Ланка 2: Виробництво борошна } \\
\hline 1. Заробітна плата & 42,86 & 41,60 & 46,73 & 47,12 & 47,51 & $+4,65$ \\
\hline 2.Амортизація необоротних активів & 24,75 & 24,02 & 26,99 & 27,21 & 27,44 & $+2,69$ \\
\hline 3. Прибуток & 32,40 & 34,37 & 26,29 & 25,68 & 25,06 & $-7,34$ \\
\hline \multicolumn{7}{|c|}{ Ланка 3: Виробництво ХББВ нетривалого зберігання } \\
\hline 1. Заробітна плата & 55,08 & 54,21 & 58,51 & 59,18 & $\mathbf{5 9 , 5 3}$ & $+4,45$ \\
\hline 2.Амортизація необоротних активів & 23,04 & 22,68 & 24,48 & 24,76 & 24,90 & $+1,86$ \\
\hline 3. Прибуток & 21,88 & 23,11 & 17,01 & 16,06 & 15,57 & $-6,31$ \\
\hline \multicolumn{7}{|c|}{ Ланка 4: Торгівля ХББВ нетривалого зберігання } \\
\hline 1. Заробітна плата & 37,02 & 39,10 & 38,10 & 37,34 & 36,60 & $-0,42$ \\
\hline 2.Амортизація необоротних активів & 1,45 & 1,75 & 1,65 & 1,61 & 1,59 & $+0,14$ \\
\hline 3. Прибуток & 61,54 & 59,15 & 60,25 & 61,05 & 61,81 & $+0,27$ \\
\hline
\end{tabular}

*Розраховано автором за даними Державної служби статистики України, офіційних аналітичних видань [12-16], власного моніторингу

Водночас питома вага прибутку в доданій вартості переробних ланок $є$ найнижчою в ринковому ланцюгу і складає 15,6 \% і 25,1 \% для ланок виробництва борошна й хліба відповідно та має знижувальну динаміку (на 6,3 і 7,3\%). Головним ресурсоутворю- вальним елементом доданої вартості торгової ланки є прибуток (61,8 \%). За досліджуваний період структура доданої вартості торгової ланки ланцюга внутрішнього ринку ЗХП була відносно стабільною (див. табл. 3). 
Міжланкове порівняння ресурсної структури доданої вартості у ринковому ланцюгу дозволяє встановити латентні структурні диспропорції. Так, для сировинного сектору до деформацій структури доданої вартості доцільно віднести штучно завищений рівень прибутку внаслідок відсутності в собівартості зерна витрат на відновлення родючості грунтів. Існування такої деформації призводить до необ'єктивної оцінки ресурсної структури доданої вартості пшениці, завищення питомої ваги прибутку за рахунок заниження частки інших компонентів вартості.

Структурні диспропорції в секторах виробництва борошна та хліба полягають у відносно невеликій частці прибутку в структурі доданої вартості внаслідок низької рентабельності продукції (3\% і 2,7 \% відповідно). У торговельній ланці найвища питома вага прибутку в доданій вартості $(61,8 \%)$ є свідченням міжланкового перерозподілу доходів у ринковому ланцюгу на користь четвертої ланки, наближеної до кінцевих споживачів продукції.

Третім етапом діагностики є розрахунок системи індикаторів логістичних витрат у ланковому й ланцюговому вимірі, а також їх ланкової структури [11]. Державна служба статистики Україні не прово- дить спостереження в площині обліку логістичних витрат (загальних і секторальних). Учені відзначають, що склад логістичних витрат на рівні підприємства, сектору або національної економіки дуже неоднорідний. Так, К. Рантасіла і Л. Охала визначили понад $70 \%$ різних видів витрат, які були використані для оцінки логістичних витрат економік різних держав. Внаслідок розбіжностей існуючих методик міждержавні порівняння індикаторів логістичних витрат значно ускладнені [17].

Дискусійним є питання визначення логістичних видів діяльності. Світовий банк користується класифікацією, яка виділяє три сфери логістичних послуг - профільні, суміжні та непрофільні послуги, при цьому акцент зміщено на сектор вантожоперевезень [17]. У 2019 р. частка валової доданої вартості логістичних видів діяльності (оптової та роздрібної торгівлі, транспорту й складського господарства) у ВВП України досягла 20 \%, зменшившись порівняно з 2010 р. на 2,3\% (рис. 3). Таке скорочення було обумовлене одночасним зменшенням питомої ваги у ВВП двох секторів економіки (транспортного й торговельного).

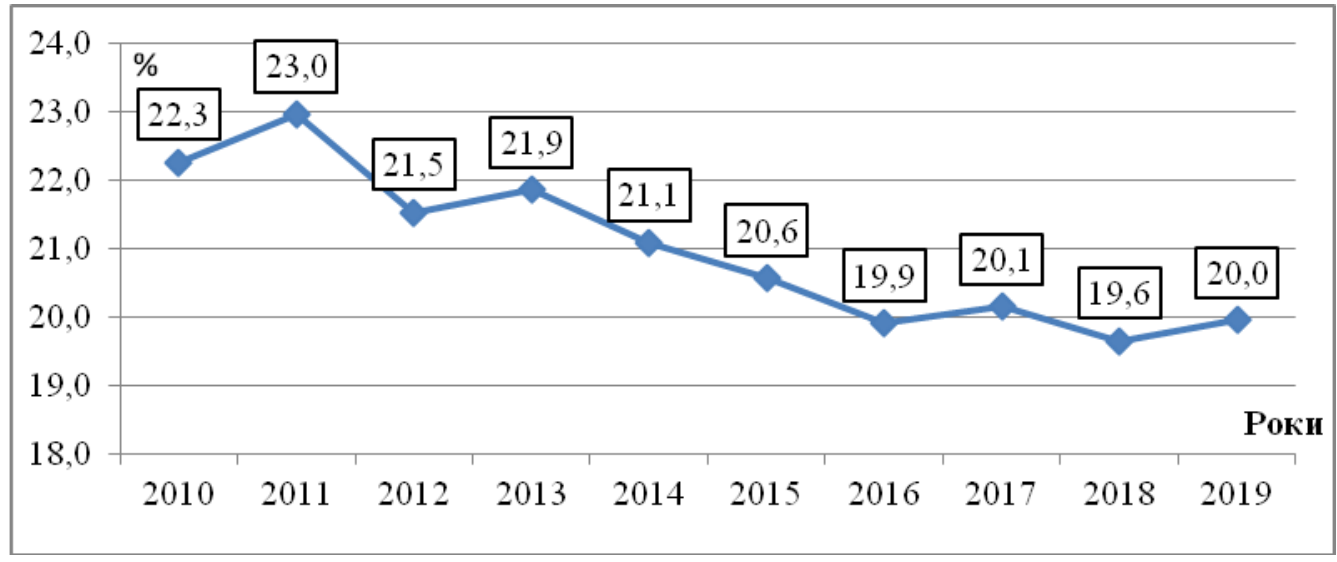

Рис. 3. Частка логістичних видів економічної діяльності у ВВП України, \%*

*Розраховано автором за даними Державної служби статистики України $[12,13]$

Частка логістичних витрат у ВВП Канади складає близько $11,8 \%$, Мексики - 15,4 \%, США 11,4\%, Франції - 11,5\%, Німеччини - 13,5\%, Великобританії - 11,5\%, Японії - 11,4\% [18, с. 313]. За даними Світового банку, загальні логістичні витрати України оцінювалися на рівні 18-20 \% ВВП [17]. Індикатор частки логістичних витрат у вартості товарів значно варіює за секторами економіки: найвища частка (до 30 \%) притаманна харчовій промисловості, найнижча (до $10 \%$ ) - машинобудівній [4, с.11].

Для розрахунку величини логістичних витрат у ринковому ланцюгу використаємо методику проф. O.М. Сумця, що базується на визначенні логістичної компоненти (тобто витрат на виконання логістичних функцій) елементів витрат (матеріальних, оплату праці, соціального внеску, амортизації необоротних активів, інших витрат) суб'єктів господарювання [4]. Величина ланкових логістичних витрат дає змогу розрахувати низку пов'язаних індикаторів, зокрема, частку логістичних витрат у випуску та собівартості продукції певної ланки ринкового ланцюга, логістичну компоненту доданої вартості та іiі питому вагу у ланковій новоствореній вартості. Слід зазначити, що два останніх індикатори є авторськими, вперше запропонованими для діагностики ефективності ринкових ланцюгів [11].

На підставі офіційної статистичної та аналітичної інформації [12-16], даних власного моніторингу за 2015-2019 pр., розраховано комплекс показників логістичних витрат у ланцюгу вітчизняного ринку ЗХП. Результати проведених розрахунків узагальнено в таблиці 4. 
Динаміка індикаторів ланкових логістичних витрат (ЛВ) у ланцюгу українського ринку зернових і хлібних продуктів, \%"

\begin{tabular}{|c|c|c|c|c|c|c|}
\hline \multirow{2}{*}{ Індикатори } & \multicolumn{5}{|c|}{ Роки } & \multirow{2}{*}{$\begin{array}{l}\text { Динаміка } \\
\text { змін }(+,-)\end{array}$} \\
\hline & 2015 & 2016 & 2017 & 2018 & 2019 & \\
\hline \multicolumn{7}{|c|}{ Ланка 1: Виробництво пшениці } \\
\hline $\begin{array}{l}\text { 1. Ланкові логістичні витрати, млн. } \\
\text { грн. }\end{array}$ & 675,4 & 807,8 & 1102,5 & 1216,8 & 982,3 & $+307,0$ \\
\hline 2. Частка ЛВ у випуску продукції & 20,90 & 22,00 & 24,81 & 25,07 & 24,85 & $+4,58$ \\
\hline $\begin{array}{l}\text { 3. Частка ЛВ у собівартості продук- } \\
\text { ції }\end{array}$ & 28,51 & 28,97 & 31,46 & 31,23 & 30,10 & $+2,34$ \\
\hline $\begin{array}{l}\text { 4. Логістична компонента ДВ, млн. } \\
\text { грн. }\end{array}$ & 290,5 & 362,7 & 641,4 & 700,0 & 549,3 & $+258,8$ \\
\hline 5. Частка ЛВ у доданій вартості, \% & 20,46 & 23,64 & 37,74 & 37,90 & 48,64 & $+19,60$ \\
\hline 6. Частка ланки у ланцюгових ЛВ, \% & 12,29 & 11,89 & 13,94 & 14,31 & 11,15 & $-1,13$ \\
\hline \multicolumn{7}{|c|}{ Ланка 2: Виробництво борошна } \\
\hline $\begin{array}{l}\text { 1.Ланкові логістичні витрати, млн. } \\
\text { грн. }\end{array}$ & 473,3 & 516,3 & 569,3 & 588,6 & 599,6 & $+126,3$ \\
\hline 2.Частка ЛВ у випуску продукції & 11,29 & 11,60 & 11,99 & 12,08 & 12,10 & $+0,80$ \\
\hline $\begin{array}{l}\text { 3. Частка ЛВ у собівартості продук- } \\
\text { ції }\end{array}$ & 11,78 & 12,15 & 12,38 & 12,46 & 12,46 & $+0,68$ \\
\hline $\begin{array}{l}\text { 4. Логістична компонента ДВ, млн. } \\
\text { грн. }\end{array}$ & 45,89 & 48,62 & 52,69 & 53,99 & 54,99 & $+9,10$ \\
\hline 5. Частка ЛВ у доданій вартості, \% & 8,60 & 8,36 & 9,41 & 9,46 & 9,54 & $+0,94$ \\
\hline 6. Частка ланки у ланцюгових ЛВ, \% & 8,61 & 7,60 & 7,20 & 6,92 & $\mathbf{6 , 8 1}$ & $-1,80$ \\
\hline \multicolumn{7}{|c|}{ Ланка 3: Виробництво ХББВ нетривалого зберігання } \\
\hline $\begin{array}{l}\text { 1. Ланкові логістичні витрати, млн. } \\
\text { грн. }\end{array}$ & 1305,6 & 1526,0 & 1752,3 & 1879,7 & 2003,5 & $+698,0$ \\
\hline 2. Частка ЛВ у випуску продукції & 15,20 & 15,38 & 15,91 & 16,08 & 16,11 & $+0,91$ \\
\hline $\begin{array}{l}\text { 3. Частка ЛВ у собівартості продук- } \\
\text { ції }\end{array}$ & 15,82 & 16,06 & 16,39 & 16,53 & 16,55 & $+0,72$ \\
\hline $\begin{array}{l}\text { 4. Логістична компонента ДВ, млн. } \\
\text { грн. }\end{array}$ & 194,96 & 224,55 & 253,54 & 269,71 & 287,59 & $+92,63$ \\
\hline 5. Частка ЛВ у доданій вартості, \% & 12,61 & 12,41 & 13,44 & 13,60 & 13,70 & $+1,09$ \\
\hline 6. Частка ланки у ланцюгових ЛВ, \% & 23,75 & 22,46 & 22,15 & 22,10 & 22,75 & $-1,00$ \\
\hline \multicolumn{7}{|c|}{ Ланка 4: Торгівля ХББВ нетривалого зберігання } \\
\hline $\begin{array}{l}\text { 1. Ланкові логістичні витрати, млн. } \\
\text { грн. }\end{array}$ & 3043,3 & 3943,7 & 4485,7 & 4819,5 & 5221,7 & $+2178,4$ \\
\hline 2. Частка ЛВ у випуску продукції & 33,59 & 37,50 & 38,00 & 38,34 & 38,88 & $+5,30$ \\
\hline $\begin{array}{l}\text { 3. Частка ЛВ у собівартості продук- } \\
\text { ції }\end{array}$ & 34,70 & 38,80 & 39,60 & 40,05 & 40,75 & $+6,05$ \\
\hline $\begin{array}{l}\text { 4. Логістична компонента ДВ, млн. } \\
\text { грн. }\end{array}$ & 63,06 & 94,35 & 124,81 & 136,79 & 154,80 & $+91,74$ \\
\hline 5. Частка ЛВ у доданій вартості, \% & 13,35 & 15,85 & 15,74 & 15,60 & 15,56 & $+2,21$ \\
\hline 6. Частка ланки у ланцюгових ЛВ, \% & 55,36 & 58,05 & 56,71 & 56,67 & 59,29 & $+3,93$ \\
\hline Загальні ланцюгові ЛВ, млн. грн. & $\mathbf{5 4 9 7 , 5 6}$ & 6793,93 & 7909,79 & 8504,68 & $\mathbf{8 8 0 7 , 1 7}$ & $+3309,61$ \\
\hline
\end{tabular}

Розраховано автором за даними Державної служби статистики України, офіційних аналітичних видань [12-16], власного моніторингу. 
У 2019 р. порівняно з 2015 р. характерною є тенденція зростання обсягів логістичних витрат у всіх ланках ринкового ланцюга, при цьому темп їх приросту перевищує аналогічний показник для собівартості продукції. Так, найвищі темпи приросту логістичних витрат притаманні торговельній та переробній хлібній ланкам (72\% і 53 \%), при цьому темп приросту ланкової собівартості склав 46,1 \% і 46,7 \% відповідно. За досліджуваний період у сировинній і торговельній ланках ланцюга ринку ЗХП темп приросту логістичної компоненти доданої вартості (89 \% і $145 \%)$ перевищував аналогічний показник для ланкових логістичних витрат (45\% і $72 \%$ відповідно). Таке спів- відношення є свідченням наявності у цих секторах потенціалу скорочення логістичних витрат. Для переробних ланок ринкового ланцюга притаманне зворотне співвідношення (див. табл. 4).

У звітному році порівняно з 2015 р. загальні ланцюгові логістичні витрати зросли на 60,2\% i склали 8,8 млрд. грн. У ланковій структурі ланцюгових логістичних витрат найбільша частка припадає на торговельний сектор (59,3% в 2019 р.) та виробництво ХББВ нетривалого зберігання (22,8 \%). За досліджуваний період питома вага торговельної ланки зросла майже на $4 \%$ за рахунок скорочення часток інших ланок ринкового ланцюга (рис. 4).

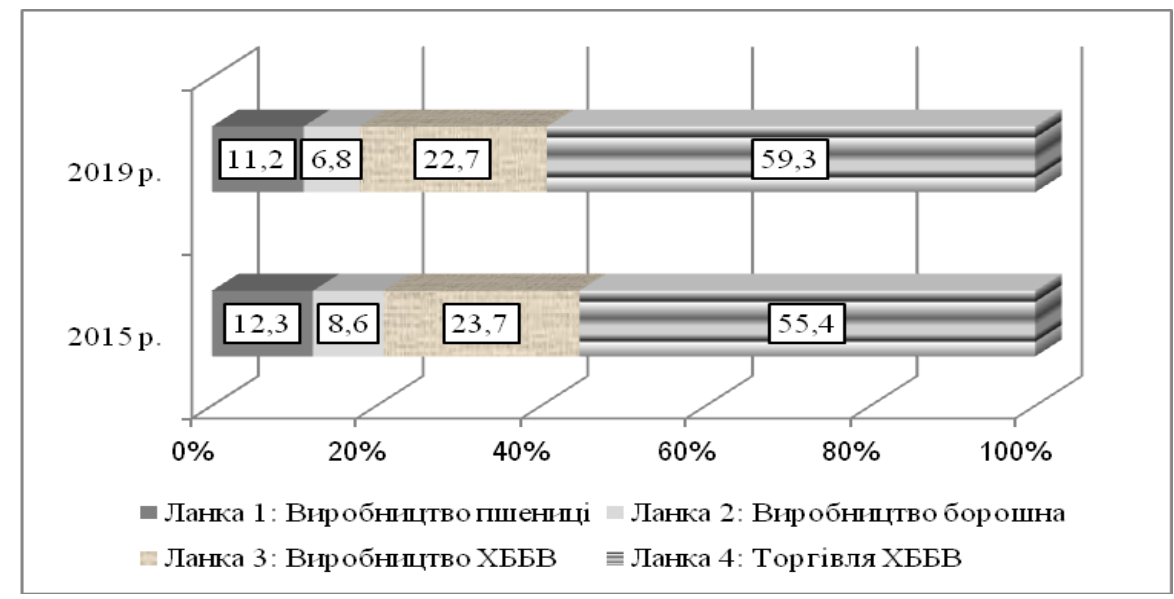

Рис. 4. Ланкова структура логістичних витрат у ланцюгу ринку зернових і хлібних продуктів України, \%* "Побудовано автором за даними табл. 4.

Показник частки логістичних витрат у випуску продукції найвищим $є$ у сировинній і торговельній ланках логістичного ланцюга ринку ЗХП (24,9 \% i $38,9 \%$ у 2019 р.) та має тенденцію до зростання (понад $5 \%$ ). У переробних ланках даний індикатор є вдвічі нижчим і складає $12,1 \%$ для борошна і $16,1 \%$ для хліба (див. табл. 4). За 2015-2019 рр. найвищий рівень частки логістичних витрат у собівартості продукції притаманний торговельній і сировинній ланкам ринкового ланцюга (40,8 \% і 30,1 \%); у переробних ланках величина індикатора $\epsilon$ вдвічі нижчою i складає $12,1 \%$ і $16,6 \%$ відповідно.

У звітному році питома вага логістичних витрат у доданій вартості сировинної ланки досягла 48,6 \%, збільшившись порівняно з 2015 р. вдвічі. Рівень даного показника у зерновій ланці $є$ значно вищим його величини у переробних (9,5\% і 13,7\%) та торговельній $(15,6 \%)$ ланках логістичного ланцюга ринку ЗХП (див. табл. 4). За аналітичними даними, частка логістичних витрат у собівартості реалізованого зерна коливається від 30 до 50 \%. Питома вага логістичних витрат у експортній ціні пшениці складає близько $30 \%$, кукурудзи - 40 \% [14]. За дослідженнями науковців, у 2018 р. величина логістичних витрат при експорті пшениці досягала 757,5 грн. / т (без ПДВ), 3 них 77 \% припадало на транспортні витрати, $23 \%$ - послуги елеваторів [7, с. 105]. Наведені дані є свідченням вагомого впливу логістичних витрат на ефективність зернової ланки ринкового ланцюга, що актуалізує завдання оптимізації управління цими витратами та пошуку резервів їх скорочення на інноваційній основі.

За розрахунками О.М. Сумця, усереднені частки логістичних витрат за етапами товароруху в мікрологістичній системі складають для ланок постачання $23,5 \%$, виробництва $-14,2 \%$, розподілу і збуту 40,8 \%, повернення - 4,9\%, утилізації та знищення відходів - 16,7 \% [4, с. 102]. У ході проведеного дослідження для макрологістичної системи ринку було отримано інші значення індикаторів (див. табл. 4), які відображають особливості відтворювальнологістичних процесів ринку ЗХП.

Завершальним етапом діагностики ефективності ринкових ланцюгів $є$ проведення порівняльного аналізу головних показників доданої вартості та логістичних витрат на основі міжланкового балансу ефективності. Даний баланс дозволяє визначити причинно-наслідкові зв'язки й залежності між відтворювально-логістичними процесами складових ланок ланцюга, а також обгрунтувати міжланкові співвідношення показників ефективності в товаропровідному ланцюгу ринку. На підставі результатів проведеної діагностики (див. табл. 2, 4) сформовано міжланковий баланс показників ефективності ланцюга вітчизняного ринку ЗХП у 2019 році (таблиця 6). 
Таблиця 6

Міжланковий баланс показників доданої вартості та логістичних витрат у ланцюгу українського ринку ЗХП у 2019 р., \%*

\begin{tabular}{|c|c|c|c|c|c|}
\hline Індикатори & $\begin{array}{l}\text { Умовні } \\
\text { позна- } \\
\text { чення }\end{array}$ & $\begin{array}{c}\text { Ланка 1: } \\
\text { Виробництво } \\
\text { Пшениці }\end{array}$ & $\begin{array}{c}\text { Ланка 2: Ви- } \\
\text { робництво } \\
\text { борошна }\end{array}$ & $\begin{array}{c}\text { Ланка 3: } \\
\text { Виробницт- } \\
\text { во ХББВ }\end{array}$ & $\begin{array}{c}\text { Ланка } 4 \\
\text { Торгівля } \\
\text { ХББВ }\end{array}$ \\
\hline $\begin{array}{l}\text { 1. Частка ланки у ланцюговій } \\
\text { доданій вартості }\end{array}$ & $\mathbf{Y}_{\text {Дв }}$ & 23,53 & 12,01 & 43,74 & 20,73 \\
\hline $\begin{array}{l}\text { 2. Частка доданої вартості у ви- } \\
\text { пуску продукції }\end{array}$ & $\mathbf{Y}_{\text {ДВВ }}$ & 28,57 & 11,62 & 16,88 & 7,41 \\
\hline $\begin{array}{l}\text { 3. Відтворювальна рентабель- } \\
\text { ність продукції }\end{array}$ & PB & 34,60 & 11,97 & 17,34 & 7,76 \\
\hline 4.Рентабельніть продукції & $\mathbf{P}$ & 11,80 & 3,00 & 2,70 & 4,80 \\
\hline $\begin{array}{l}\text { 5.Податкомісткість доданої вар- } \\
\text { тості }\end{array}$ & $\Pi_{\text {Дв }}$ & 10,11 & 33,08 & 33,54 & 28,61 \\
\hline $\begin{array}{l}\text { 6. Частка ланки у ланцюгових } \\
\text { логістичних витратах }\end{array}$ & ЛВ & 11,15 & 6,81 & 22,75 & 59,29 \\
\hline $\begin{array}{l}\text { 7. Частка логістичних витрат у } \\
\text { собівартості продукції }\end{array}$ & $\mathbf{Y}_{\text {ЛВС }}$ & 30,10 & 12,46 & 16,55 & 40,75 \\
\hline $\begin{array}{l}\text { 8. Частка логістичних витрат у } \\
\text { доданій вартості }\end{array}$ & 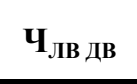 & 48,64 & 9,54 & 13,70 & 15,56 \\
\hline
\end{tabular}

Сформовано автором за даними табл. 2, 4

У 2019 р. найвища частка у ланцюговій доданій вартості притаманна ланці виробництва ХХБВ (у 2015-2018 рр. різниця між частками сировинної й переробної ланок складала 3-4 \%, у 2019 р. вона поглибилися до $20 \%$ внаслідок подвійного скорочення рентабельності пшениці - див. табл. 2), найвища питома вага доданої вартості у випуску продукції характерна для зернової ланки (за 2015-2019 рр. індикатор скоротився на 15 \%). Відтак, у звітному періоді формування доданої вартості в ланцюгу ринку ЗХП здійснювалося в координатах таких міжланкових нерівностей:

$$
\begin{aligned}
& \mathbf{U}_{\text {ДВ 3 }}>\mathbf{U}_{\text {ДВ 1 }}>\mathbf{U}_{\text {ДВ 3 }}>\mathbf{U}_{\text {ДВ 2 }} \\
& \mathbf{U}_{\text {ДВВ } 1}>\mathbf{U}_{\text {ДВВ } 3}>\mathbf{U}_{\text {ДВВ 2 }}>\mathbf{U}_{\text {ДВ } 4}
\end{aligned}
$$

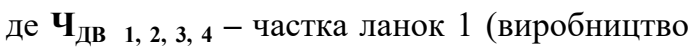
пшениці), 2 (виробництво борошна), 3 (виробництво ХББВ нетривалого зберігання), 4 (торгівлі ХББВ) у ланцюговій доданій вартості (див. табл. 6).

Незважаючи на падіння доходності зерна в 2019 р., сировинна ланка лідирує за рівнями відтворювальної рентабельності та рентабельності продукції, маючи при цьому найнижчі значення податкомісткості доданої вартості в ринковому ланцюгу. Тобто мають місце нерівності:

$$
\begin{aligned}
& \mathrm{PB}_{1}>\mathrm{PB}_{3}>\mathrm{PB}_{2}>\mathrm{PB}_{4} \\
& P_{1}>P_{4}>P_{2} \geq P_{3}
\end{aligned}
$$

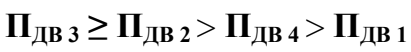

Проведені розрахунки свідчать (див. табл. 6), що у міру поглиблення ступеню переробки сировини в логістичному ланцюгу «пшениця - борошно ХББВ нетривалого зберігання» податкомісткість доданої вартості зростає, максимізуючись у хлібній ла- нці. Міжланкові нерівності вказують на існування диспропорції у фіскальному розподілі доданої вартості, яка полягає в тому, що найвищий рівень податкового навантаження (54,4 \%) припадає на ланку виробництва ХХБВ, яка при цьому має найнижчий рівень рентабельності продукції (2,7 \%), та найвищу трудомісткість доданої вартості (59,5 \%) у ринковому ланцюгу. Відтак, хлібна ланка виконує вагомі соціальні та податкові функції в ринковій системі, водночас іiі відтворювальна функція залишається нереалізованою 3 причини низької доходності промислового виробництва хліба в країні та надмірного податкового навантаження на соціально орієнтовані хлібопекарські підприємства.

У 2019 р. найвища питома вага у ланцюгових логістичних витратах притаманна торговельній ланці $(59,3 \%)$, також вона має найвище значення частки логістичних витрат у собівартості продукції (41,8 \%), тобто справедливі такі нерівності:

$$
\begin{aligned}
& Л_{2}<\boldsymbol{I B}_{1}<\boldsymbol{Л B}_{3}<\boldsymbol{Л B}_{4} \\
& \mathbf{Y}_{\text {ЛВС } 2}<\mathbf{Y}_{\text {ЛВС } 3}<\mathbf{Y}_{\text {ЛВС } 1}<\mathbf{Y}_{\text {ЛВС } 4} \\
& \mathbf{Ч}_{\text {ЛВ ДВ } 2}<\mathbf{Ч}_{\text {ЛВ ДВ } 3}<\text { Ч }_{\text {ЛВ ДВ } 2}<\text { Ч ЛВ ДВ } 1
\end{aligned}
$$

Логістичні витрати сировинної ланки ланцюга ринку ЗХП займають вагомі частки у ланковій доданій вартості $(48,6 \%)$ та собівартості продукції $(30,1 \%)$. Це є свідченням наявності потенціалу скорочення логістичних витрат у ланці зерновиробництва та оптимізації їх величини для підвищення ефективності даної ланки.

Визначені за результатами емпіричного дослідження міжланкові нерівності (1) - (8) головних показників доданої вартості та логістичних витрат у ланцюгу вітчизняного ринку ЗХП формують наукове підгрунтя, з одного боку, для встановлення структур- 
них і фінансових диспропорцій у ланцюгах вартості, 3 іншого, для обгрунтування інституційних механізмів точкового впливу на ці диспропорції з метою їх нівелювання та досягнення цільових орієнтирів відтворювальної логістики товарних ринків.

Висновки та перспективи подальших досліджень. На основі емпіричних досліджень визначено співвідношення показників ефективності різних ланок ланцюга ринку ЗХП, структурні диспропорції у формуванні й розподілі доданої вартості в ринковому ланцюгу. Встановлено, що у міру зростання ступеню переробки продукції в ланцюгу «пшениця - борошно - хліб», рівень іiі рентабельності зменшується за одночасного зростання податкового навантаження та податкомісткості доданої вартості. Діагностика ресурсної структури доданої вартості визначила низку диспропорцій, які гальмують відтворювальний розвиток переробних ланок ланцюга, передусім ланки виробництва ХББВ нетривалого зберігання. Дана ланка генерує майже 44 \% ланцюгової доданої вартості, має найвищу частку заробітної плати (60 \%) та найнижчу частку прибутку $(15,6$ \%) в структурі вартості, завищений рівень податкомісткості доданої вартості $(33,5$ грн. / грн.), що свідчить про реалізацію соціальної і податкової функції хлібної ланки та низький ступінь впровадження іiі відтворювальної функції в напрямі забезпечення розширеного відтворення та доходності соціально орієнтованих хлібопекарських підприємств.

Наслідком трансформаційного впливу недосконалих інститутів на розвиток ланки виробництва ХББВ в Україні стало перманентне зростання іiі «тіньового» сегменту та його активна взаємодія із «тіньовою» сферою суміжної борошняної ланки ланцюга ринку ЗХП. За оцінками експертів, «тіньовий» сегмент ринку хлібобулочних виробів в Україні складає понад $65 \%$, ринку борошна - близько $40 \%$ [14, 19]. Невирішеність питання оптимізації відтворювальних пропорцій у ланцюгу ринку ЗХП призвела, з одного боку, до міграції значної частини доданої вартості у сфери нерегламентованого товароруху переробних ланок, з іншого, до стійкого скорочення обсягів товаропотоків у промисловій сфері (регламентованого товароруху) цих ланок. За даними Держстату, у 2019 р. порівняно з 2015 р. обсяги промислового виробництва ХББВ скоротилися на $27,5 \%$, борошна на 15,5 \% [13]. Відтак, на практиці відбувається трансформація ланцюга ринку ЗХП в напрямі скорочення завершеного циклу переробки, міграції доданої вартості у «тіньові» сфери переробних ланок, що генерує податкові втрати для держави, соціальні втрати для населення й економічні втрати для промислових підприємств.

Діагностика логістичних витрат дозволила встановити такі міжланкові співвідношення. У ланко- вій структурі логістичних витрат найбільша частка припадає на торговельний сектор (59 \%) та виробництво хлібобулочних виробів (23\%). Найвищий рівень частки логістичних витрат у собівартості продукції притаманний торговельній (41\%) і сировинній ланкам (30\%) ланцюга; у переробних ланках рівень індикатора є вдвічі нижчим. У дослідженні вперше розраховано логістичну компоненту доданої вартості, встановлено іiі найбільше значення (49\%) та зростаючий тренд у зерновій ланці, що обумовлює необхідність пошуку резервів скорочення витрат на інноваційній основі.

На основі міжланкового балансу головних показників ефективності ланцюга ринку ЗХП проведено їх порівняльний аналіз та визначено співвідношення індикаторів доданої вартості й логістичних витрат у ланковому вимірі, низку міжланкових нерівностей, як підгрунтя для обгрунтування механізмів державного впливу на відтворювальні диспропорції.

Завдання продовження ланцюга доданої вартості, як мультиплікатора для розвитку агропромислового сектору, є вагомою складовою стратегічної цілі 5 «Сприяння розвитку та повноцінному забезпеченню ринку для функціонування переробки» Національної економічної стратегії на період до 2030 року [1]. Його впровадження на ринку зернових і хлібних продуктів України передбачає, з одного боку, реалізацію низки стимулюючих механізмів і заходів для забезпечення стійкого відтворювального розвитку соціально орієнтованих хлібопекарських підприємств, з іншого, затвердження ефективного технічного регулювання та ринкового нагляду, поетапну «детінізацію» ланок ринкового ланцюга. Також важливим інструментом продовження ланцюга вартості $€$ стимулювання експорту борошномельної продукції, підтримка вітчизняних експортерів на зовнішніх ринках збуту, що відповідає шляхам досягнення стратегічної цілі 6 «Оптимізація системи збуту продукції на внутрішньому та зовнішньому ринках» Національної економічної стратегії [1].

Наукова новизна проведеного дослідження полягає в розвитку методології логістики товарних ринків у частині обгрунтування відтворювальних диспропорцій у ланцюгу українського ринку ЗХП, міжланкових співвідношень показників доданої вартості і логістичних витрат, що формує наукове підгрунтя для розробки та впровадження адаптивних механізмів i інструментів для продовження ланцюга вартості та забезпечення його ефективного функціонування. Перспективами подальших досліджень у даному напрямі $є$ розробка на основі сформованої аналітичної бази інституційно-економічних механізмів відтворювально-логістичного розвитку вітчизняного ринку ЗХП в умовах економічної нестабільності.

\section{Література}

1. Національна економічна стратегія на період до 2030 року: затверджено постановою Кабінету Міністрів України від 3 березня 2021 р. №179. URL: https://www.kmu.gov.ua/npas/pro-zatverdzhennya-nacionalnoyi-eko-a179 (дата звернення 15.03.21) 
2. Гірна О. Б., Глинський Н.Ю., Кобилюх О.Я. Формування доданої вартості для клієнта в ланцюгу поставок. Логістика: теорія та практика. 2012. № 1(2). С. 39-46.

3. Посилкіна О.В. Логістичний менеджмент фармацевтичного підприємства: монографія. Харків: Вид-во нац. фарм. ун-ту, 2011. 772 с.

4. Сумець О.М. Логістичні витрати підприємств олійно-жирової галузі: формування та оцінювання: монографія. Харків: Видавництво НУА, 2017. 243 с.

5. Горячук В.Ф., Назаренко Ю.А. Методичні засади оцінки капіталізації підприємств. Вісник соціальноекономічних досліджень. 2018. №4 (68). С.20-29. doi: 10.33987/vsed.4(68).2018.20-29

6. Коваленко О.В. Додана вартість у контексті національної продовольчої безпеки. Економіка та держава. 2015. №4. С. 98 - 102 .

7. Педорченко А.Л., Шпичак О.О. Дієвість податку на додану вартість при експорті продукції рослинництва. Економіка АПК. 2020. №1. С.101 - 110. doi: 10.32317/2221-1055.202001101

8. Буркинський Б.В., Лисюк В.М., Тараканов М.Л. та ін. Методологічні засади формування ефективної логістики товарних ринків: монографія. Одеса: ІПРЕЕД НАН України, 2020. 200 с.

9. Нікішина О.В., Тараканов М.Л. Теоретико-методичні засади логістичних «розривів» у ланцюгах товарних ринків. Food Industry Economics. 2020. 12 (4). C. 3-16. URL: https://journals.onaft.edu.ua/index.php/fie/article/view/1906. doi: 10.15673/fie.v12i4. (дата звернення 12.03.21)

10. Nikishyna O.V., Lozova T.P. Formation of effective cooperative value chains on the agricultural food markets of Ukraine. Economic innovations. 2021. Vol. 23. №1 (78). P.152-161. doi: 10.31520/ei.2021.23.1(78).152-161

11. Нікішина О.В. Методичні положення діагностики ефективності функціонування логістичних ланцюгів товарних ринків. Food Industry Economics. $2020.12 \quad$ (3). C. 3-16. URL: https://journals.onaft.edu.ua/index.php/fie/article/view/181. doi: 10.15673/fie.v12i3.1811 (дата звернення 12.03.21)

12. Офіційний сайт Державної служби статистики України. URL: http://www.ukrstat.gov.ua/ (дата звернення 15.03.21)

13. Статистичний щорічник України за 2019 рік. За ред. І.Є.Вернера. Київ: Державна служба статистики України, 2020. 430с.

14. Офіційний сайт інформаційно-аналітичного агентства «АПК-Інформ». URL: https://www.apkinform.com/uk (дата звернення 15.03.21)

15. Витрати на виробництво продукції сільського господарства в сільськогосподарських підприємствах у 2018 році: статистичний бюлетень. URL: http://www.ukrstat.gov.ua/ (дата звернення 17.03.21)

16. Діяльність суб’єктів господарювання 2019: статистичний збірник / За ред. М. С. Кузнєцової. К.: Державна служба статистики України, 2020. 153 с.

17. Rantasila K, Ojala L. National-level logistics costs: an overview of extant research. International Journal of Logistics Research and $2015 . \quad$ Volume $18 . \quad$ URL: https://www.tandfonline.com/doi/abs/10.1080/13675567.2015.1016413 (дата звернення 17.03.21)

18. Стратегія сталої логістики та План дій для України: проект для розгляду. Міністерство інфраструктури України, World Bank Group. URL: https://mtu.gov.ua/files/Logistics.pdf . doi: 10.1080/13675567.2015.1016413 (дата звернення 17.03.21)

19. В Україні названо обсяги «тіньового» ринку борошна (інтерв’ю голови ревізійної комісії ГС «Борошномели України» С. Сакіркіна). URL: https://agronews.ua/news/v-ukraini-nazvano-obsiahy-tinovoho-rynku-boroshna (дата звернення 17.03.21)

Стаття надійшла 25.03.2021 Стаття прийнята до друку 19.04.2021 Доступно в мережі Internet 21.07.2021

\author{
Nikishyna 0. \\ Doctor of Economics, Senior Researcher \\ Head of Department of Market Mechanisms and Structures \\ Institute of Market Problems and Economic \& Ecological Research \\ of National Academy of Sciences of Ukraine \\ Frantsuzskiy boulevard, 29, Odesa, Ukraine, 65044 \\ E-mail: ksenkych@gmail.com \\ ORCID ID: 0000-0002-7172-3551
}

\title{
DIAGNOSTICS OF VALUE ADDED AND LOGISTICS COSTS INDICES IN THE CHAIN OF GRAIN AND BREAD PRODUCTS OF UKRAINE
}

The article is devoted to the empirical study of the indicators of value added and logistics costs in the chain of grain and bread products of Ukraine. The interlink ratios of the main efficiency indicators and reproduction disproportions in the development of the market chain have been determined. It has been established that 
as the degree of processing of products in the chain «wheat - flour - bread» increases, its level of profitability decreases with a simultaneous increase in the tax burden and changes in the structure of value added in the direction of increasing the share of wages and reducing specific gravity of profits. It has been proved that the link of bakery products production, playing an important social and tax role in the market system, lacks added value, which inhibits its reproduction development on an innovative basis.

It has been emphasized that the unresolved problem of structural disparities in the chain of grain and bread products is gradually transforming this chain in the direction of reducing the completed processing cycle and migration of value added in the "shadow» spheres of processing units. The diagnostics of logistics costs in the unit dimension has been carried out, the logistics component of value added has been calculated for the first time, its greatest value and the growing trend in the raw material link have been established. Based on the inter-link balance of market chain efficiency indicators, their comparative analysis has been carried out and a number of inter-link inequalities have been identified as a basis for the introduction of adaptive mechanisms and measures to overcome reproduction imbalances in the value chain.

Directions and measures of continuation of the market value chain in the context of achieving the goals of the National Economic Strategy until 2030 have been defined, namely: approval of effective technical regulation and market surveillance, gradual «de-shadowing» of the market chain links, stimulating flour exports, supporting domestic exporters in foreign markets.

Key words: market chain, diagnostics, added value, logistics costs, grain and bread products, reproduction development.

\section{References}

1. Natsionalna ekonomichna stratehiia na period do 2030 roku: zatverdzheno postanovoiu Kabinetu Ministriv Ukrainy vid 3 bereznia 2021 r. №179. https://www.kmu.gov.ua/npas/pro-zatverdzhennya-nacionalnoyi-eko-a179

2. Hirna, O. B., Hlynskyi, N. Yu., \& Kobyliukh, O. Ya. (2012). Formuvannia dodanoi vartosti dlia kliienta v lantsiuhu postavok. Lohistyka: teoriia ta praktyka, 1(2), 39-46.

3. Posylkina, O. V. (2011). Lohistychnyi menedzhment farmatsevtychnoho pidpryiemstva. Vyd-vo nats. farm. un-tu.

4. Sumets, O. M. (2017). Lohistychni vytraty pidpryiemstv oliino-zhyrovoi haluzi: formuvannia ta otsiniuvannia: monohrafiia. Kharkiv: Vydavnytstvo NUA.

5. Horiachuk, V. F., \& Nazarenko, Yu. A. (2018). Metodychni zasady otsinky kapitalizatsii pidpryiemstv. Visnyk sotsialno-ekonomichnykh doslidzhen, (68), 20-29. doi: 10.33987/vsed.4(68).2018.20-29

6. Kovalenko, O. V. (2015). Dodana vartist u konteksti natsionalnoi prodovolchoi bezpeky. Ekonomika ta derzhava, (4), 98 - 102.

7. Pedorchenko, A. L., \& Shpychak, O. O. (2020). Diievist podatku na dodanu vartist pry eksporti produktsii roslynnytstva. Ekonomika APK, (1), 101 - 110. doi: 10.32317/2221-1055.202001101

8. Burkynskyi, B. V., Lysiuk, V. M., \& Tarakanov, M. L. (2020). Metodolohichni zasady formuvannia efektyvnoi lohistyky tovarnykh rynkiv. IPREED NAN Ukrainy.

9. Nikishyna, O. V., \& Tarakanov, M. L. (2020). Teoretyko-metodychni zasady lohistychnykh «rozryviv»u lantsiuhakh tovarnykh rynkiv. Food Industry Economics, 12(4), 3-16. https://goo.su/6nX8 doi: 10.15673/fie.v12i4.1906

10. Nikishyna, O. V., \& Lozova, T. P. (2021). Formation of effective cooperative value chains on the agricultural food markets of Ukraine. Economic innovations, 23(1(78), 152-161. doi: 10.31520/ei.2021.23.1(78).152161

11. Nikishyna, O. V. (2020). Metodychni polozhennia diahnostyky efektyvnosti funktsionuvannia lohistychnykh lantsiuhiv tovarnykh rynkiv. Food Industry Economics, 12(3), 3-16. https://journals.onaft.edu.ua/index.php/fie/article/view/1811 doi: 10.15673/fie.v12i3.1811

12. Ofitsiinyi sait Derzhavnoi sluzhby statystyky Ukrainy (2021). http://www.ukrstat.gov.ua/

13. Vernera, I. Ye. (Ed.). Statystychnyi shchorichnyk Ukrainy za 2019 rik (2020). Derzhavna sluzhba statystyky Ukrainy.

14. Ofitsiinyi sait informatsiino-analitychnoho ahentstva «APK-Inform» (2021). https://www.apkinform.com/uk

15. Vytraty na vyrobnytstvo produktsii silskoho hospodarstva $v$ silskohospodarskykh pidpryiemstvakh u 2018 rotsi. (2019). Statystychnyi biuleten. http://www.ukrstat.gov.ua/ Ukrainy.

16. Kuznietsova, M. S. (Ed.). (2020). Diialnist subiektiv hospodariuvannia 2019. Derzhavna sluzhba statystyky

17. Rantasila, K, \& Ojala, L. (2015). National-level logistics costs: an overview of extant research. International Journal of Logistics Research and Applications, 18. https://www.tandfonline.com/doi/abs/10.1080/13675567.2015.1016413 doi: 10.1080/13675567.2015.1016413 
18. Stratehiia staloi lohistyky ta Plan dii dlia Ukrainy: proekt dlia rozghliadu. Ministerstvo infrastruktury Ukrainy (2018). World Bank Group. https://mtu.gov.ua/files/Logistics.pdf

19. V Ukraini nazvano obsiahy «tinovoho» rynku boroshna (interviu holovy reviziinoi komisii HS «Boroshnomely Ukrainy» S. Sakirkina) (2019). https://agronews.ua/news/v-ukraini-nazvano-obsiahy-tinovoho-rynkuboroshna.

Received 25 March 2021

Approved 19 April 2021

Available in Internet 21.07.2021

Цитування згідно ДСТУ 8302:2015

Нікішина О.В. Діагностика показників доданої вартості та логістичних витрат у ланцюгу ринку зернових і хлібних продуктів України // Економіка харчової промисловості. 2021. Т. 13, вип. 2. С. 9-21. doi: 10.15673/fie.v13i2.2035

Cite as APA style citation

Nikishyna, O. (2021). Diagnostics of value added and logistics costs indices in the chain of grain and bread products of Ukraine. Food Industry Economics, 13(2), 9-21. doi: 10.15673/fie.v13i2.2035 